\title{
Selenium supply affects chlorophyll concentration and biomass production of maize (Zea mays L.)
}

\author{
Selendüngung beeinflusst die Chlorophyllkonzentration \\ und die Biomassebildung von Mais (Zea mays L.)
}

\author{
Aliu Sali ${ }^{*}$, Dukagjin Zeka ${ }^{1}$, Shukri Fetahu ${ }^{1}$, Imer Rusinovci ${ }^{1}$, Hans-Peter Kaul ${ }^{2}$

\begin{abstract}
${ }^{1}$ Department of Crop Science, Faculty of Agriculture and Veterinary, University of Prishtina, Str. Bill Clinton n.nr., 10000 Prishtina, Kosovo
${ }^{2}$ Division of Agronomy, Department of Crop Sciences, University of Natural Resources and Life Sciences, Vienna, Konrad-Lorenz-Straße 24,

3430 Tulln, Austria

* Corresponding author: sali.aliu@uni-pr.edu
\end{abstract}

Received: 23 July 2018, received in revised form: 27 November 2018, 10 December 2018

\begin{abstract}
Summary
The objective of this work was to investigate the effect of selenium (Se) on the biomass production and the contents of photosynthetically active pigments. The pot experiment included two maize genotypes: hybrid 408BC originating from Croatia and a local maize population from Kosovo. The doses of Se applied were 0, 1.30, 6.57, 13, and $26 \mathrm{mg} \mathrm{kg}^{-1}$. The lowest Se dose $\left(1.30 \mathrm{mg} \mathrm{Se} \mathrm{kg}^{-1}\right)$ had a positive effect on shoot and root biomass production as well as on the contents of chlorophyll $b(C h l-b)$, total chlorophyll, and carotenoids (just for the hybrid). Chlorophyll $a$ (Chl-a) was reduced with increasing Se doses, whereas chlorophyll $b$ (Chl-b) and total chlorophyll further increased with medium Se doses. The highest Se dose strongly reduced biomass and the contents of photosynthetically active pigments. Chl- $a$ and carotenoids positively correlated with shoot (for both genotypes) and root (for the hybrid) biomass, whereas no correlation was observed between $C h l-b$ and biomass. Low amounts of Se application are favorable for biomass production and chlorophyll and carotenoids contents, whereas high amounts of Se application negatively affect both.
\end{abstract}

Keywords: maize, selenium, chlorophyll, carotenoids, shoot-to-root ratio

\section{Zusammenfassung}

Das Ziel dieser Arbeit war es, den Einfluss von Selen (Se) auf die Biomassproduktion und die Gehalte an photosynthetisch aktiven Pigmenten von Mais zu untersuchen. Der Gefäßversuch umfasste zwei Genotyp, die Hybridesorten 408BC aus Kroatien und eine Landsorte aus dem Kosovo. Die gedüngten Mengen an Se umfassten 0, 1.30, 6.57, 13, and $26 \mathrm{mg} \mathrm{kg}^{-1}$. Die geringe Se-Menge von $\left(1.30 \mathrm{mg} \mathrm{Se} \mathrm{kg}^{-1}\right)$ hatte einen positiven Einfluss auf die Sproß- und Wurzelmasseproduktion sowie auf die Gehalte von Chlorophyll $b$ (Chl-b), Gesamtchlorophyll und die Carotinoide (nur beim Hybriden). Chlorophyll $a$ (Chl-a) nahm mit zunehmenden Mengen an Se ab, während $C h l-b$ and das Gesamtchlorophyll weiter mit mittleren Mengen an Se zunahmen. Die höchste Gabe an Se reduzierte die Biomasseproduktion und die photosynthetisch aktiven Pigmenten stark. Chl-a und die Carotinoide korrelierten positiv mit der Sproß- (bei beiden Genotpyen) und der Wurzelbiomasse (beim Hybriden). Im Gegensatz dazu korrelierten Chl- $b$ und die Biomasse nicht. Geringe Mengen an Se sind daher vorteilhaft für die Biomassproduktion und die photosynthetisch aktiven Pigmenten, während hohe Mengen beides negativ beeinflussten.

Schlagworte: Mais, Selen, Chlorophyll, Carotinoide, Sproß/Wurzel-Verhältnis 


\section{Introduction}

Maize (Zea mays L.) is an important field crop; based on area and production, it ranks on the second place among the field crops in Kosovo. Chlorophyll is naturally present in plants as a photosynthetic pigment, giving their specific coloration (Withnall et al., 2003). It is one of the most important physiological parameters, which is closely related to plant photosynthesis and growth (Wang et al., 2008; Czyczyło-Mysza et al., 2013). The molecules possess a basic skeleton structure of porphyrin with a magnesium ion in the center and a long phytol group in the tail. The major chlorophylls in plants include chlorophyll $a(C h l-a)$ and chlorophyll $b$ (Chl-b) (Garousi et al., 2015a). Chlorophylls are essential tetrapyrroles responsible for harvesting solar energy, charge separation, and electron transport in photosynthesis. They mainly capture light in the antenna complex via photosystem II, with subsequent electron transport (Taiz and Zeiger, 2009). They differ slightly only in the composition of a side chain (in Chl-a, it is $-\mathrm{CH}_{3}$, and in Chl-b, it is $-\mathrm{CHO}$ ). Leaf chlorophyll content is highly correlated with the nutritional condition and as an indicator for survival and growth of plants (Gitelson, 2003).

Selenium (Se) exists in very small amounts in humans, animals, plants, and microorganisms. Although it has an importance as microelement in small amounts, toxicity occurs at high concentrations because of the replacement of sulfur with selenium in amino acids, resulting in incorrect folding of the proteins and, consequently, nonfunctional proteins and enzymes (Gul et al., 2017). Se is essential to many organisms, including some archaea, bacteria, protozoans, green algae, and nearly all animals. In plants, Se can be found in both inorganic and organic binding forms, including selenoamino acids and methylated compounds. Se is an example of an essential element becoming limiting in food commodities because of intensive plant production. Consequently, controlling the Se uptake and metabolism in plants will be important for biofortification of food and feedstuff. The availability of Se for plants depends on soil properties, including $\mathrm{pH}$, salinity, and the content of $\mathrm{CaCO}_{3}$ (Kabata and Pendias, 2001).

Sager (2002) reported that in Europe, Se occurrence in soils, crops, and groundwater is rather low, but it may be enriched from fertilization with organic amendments or selenium-containing mineral fertilizers. In soils, Se is a naturally occurring trace element that typically ranges from 0.01 to $2 \mathrm{mg} \mathrm{kg}^{-1}$ (Hoewyk, 2013). For agriculturally used soils in eastern Austria, Se values of $0.2 \mathrm{mg} \mathrm{kg}^{-1}$ have been reported (Aichberger and Hofer, 1989).

Most plants contain rather low foliar Se, around $25 \mu \mathrm{g} \mathrm{kg}^{-1}$ and rarely exceeding $100 \mu \mathrm{g} \mathrm{kg}^{-1}$. However, some plants (Astragalus spp, Stanleya albescens, and some woody asters) exhibit a great capability to accumulate Se, and they may concentrate Se to extremely high levels above $1,000 \mathrm{mg} \mathrm{kg}^{-1}$ that may be toxic to humans and animals (Garousi et al., 2015b). Edelbauer and Eder (2001) reported from a longterm grassland experiment that Se application with either sewage sludge or mineral fertilizer increased the Se contents in the uppermost soil layer but did reduce the Se of the grass. Furthermore, foliar Se application increases stepwise the Se contents in plant components of oilseed rape in the following order: leaves $>$ stems $>$ roots $>$ siliques $~-$ seeds) (Száková et al., 2017). Despite substantial literature on Se uptake by plants and crops such as wheat, little consideration has been given to maize ( $Z$. mays L.), a low "Se indicator" plant but one of the world's most widely grown cereals. To date, there have been few publications on Se uptake and assimilation in this plant (Longchamp et al., 2011). Exogenous Se at low concentration can reduce the intensity of peroxide influence on membrane lipids, affect the activity of redox enzymes, and thereby change the oxidation-reduction status of the cell, increasing stress tolerance (Vikhreva et al., 2002). A positive influence of Se on changes in the activity and permeability of the cellular membrane may be one of the impacts of Se on plants (Filek et al., 2008). Most species of crops, however, do not appear to require Se for their growth, and, in general, these plants have a low tolerance for this element (Terry et al., 2000). Plants subjected to higher Se stress exhibit different physiological changes, including stunted root growth, reduced biomass, chlorosis, reduced photosynthetic efficiency, and ultimately plant death. Spallholz and Hoffman (2002) suggested that uptake of high concentration of Se may cause symptoms of injury including stunting of growth, chlorosis, withering and drying of leaves, decreased protein synthesis, and premature death of plants. The form in which Se appears in soils and its availability for plants are determined by many physicochemical factors such as soil $\mathrm{pH}$, oxidoreduction potential, contents of humus, clay minerals, Fe oxides and other elements, microbiological activity, and also the nature and character of the absorbing surfaces (Placzek and Patorczyk, 2014). The aim of this study was to investigate the response of maize seedlings to Se supply at different concentration in biomass accumulation, chlorophyll and carotenoids content. 


\section{Materials and Methods}

\subsection{Plant material and experimental design}

The experiment was conducted at the Department of Crop Science, Laboratory of Plant Breeding, University of Pristina. The study included two factors: maize genotype and Se application. Maize genotypes were hybrid 408BC (hybrid) originating from Croatia and a local population (LP) from Kosovo. The following Se doses per kilogram of compost were applied to observe the negative effects on plants: control with distilled water, $1.30 \mathrm{mg} \mathrm{Se} \mathrm{kg}^{-1}, 6.57 \mathrm{mg} \mathrm{Se} \mathrm{kg}^{-1}$, and high doses (13 and $26 \mathrm{mg} \mathrm{Se} \mathrm{kg}^{-1}$ ).

The seeds were disinfected using $\mathrm{NaOCl} 1 \%$ for $60 \mathrm{~min}$ and then rinsed three times with distilled and sterilized water. Maize seeds were germinated on moistened filter paper. Prepared seeds were placed on the germinator for germination (after addition of $10 \mathrm{ml}$ of $\mathrm{H}_{2} \mathrm{O}$ ) for 10 days at $25^{\circ} \mathrm{C}$. Pots were filled with compost $\left(1 \mathrm{~kg} \mathrm{pot}^{-1}\right)$ and kept in a controlled environment cabinet with a 12 -h photoperiod at $25 / 19^{\circ} \mathrm{C}$ day/night and $75 \%$ relative humidity. The size of the plastic boxes (pots) was $45 \mathrm{~cm} \times 15 \mathrm{~cm} \times 12 \mathrm{~cm}$. The compost characteristics were $\mathrm{pH}\left(\mathrm{CaCl}_{2}\right)=5.8$; mineral nitrogen $\left(\mathrm{NH}_{4}+\mathrm{NO}_{3}\right)=360 \mathrm{mg} \mathrm{kg}^{-1}\left(\mathrm{CaCl}_{2}\right.$ extract $)$; phosphorus $\left(\mathrm{P}_{2} \mathrm{O}_{5}\right)=450 \mathrm{mg} \mathrm{kg}^{-1}$; and potassium $\left(\mathrm{K}_{2} \mathrm{O}\right)=$ $600 \mathrm{mg} \mathrm{kg}^{-1}$. In total, 30 pots (2 genotypes $\times 5$ Se concentrations $\times 3$ replications) were prepared for selenium $(\mathrm{Se})$ treatments and control. Solutions with different concentration for each Se treatment were prepared. Solutions for Se application were prepared using sodium selenite pentahydrate $\left(\mathrm{Na}_{2} \mathrm{SeO}_{3} \cdot 5 \mathrm{H}_{2} \mathrm{O}\right.$ with molar mass of $263.01 \mathrm{~g}$ $\mathrm{mol}^{-1}$, with $\left.\mathrm{Se}=78.96 \mathrm{~g} \mathrm{~mol}^{-1}\right)$. A stock solution of $2.6 \mathrm{~g}$ $\mathrm{Na}_{2} \mathrm{SeO}_{3} \cdot 5 \mathrm{H}_{2} \mathrm{O} / 1,000 \mathrm{ml} \mathrm{DH} \mathrm{D}_{2} \mathrm{O}$ (or $0.01 \mathrm{M}$ ) was used. For application, the required amount of stock solution was diluted with $\mathrm{H}_{2} \mathrm{O}$ D to $1000 \mathrm{ml}$.

\subsection{Plant biomass}

After 14 days of exposure, plant samples (shoots and roots) were collected from each pot randomly. The next step was to divide the plants into roots and shoots. Roots were then washed from adhering soil. After that all samples were dried at $60^{\circ} \mathrm{C}$ for 24 hours and finally weighted.

\subsection{Chlorophyll ( $a$ and $b$ ) and carotenoids analysis}

Pigments were extracted from 60 to $80 \mathrm{mg}$ of freshly sampled leaves in $80 \%$ (v/v) acetone/water containing $\mathrm{MgCO}_{3}$
$(0.5 \%, \mathrm{w} / \mathrm{v})$ at room temperature for $24 \mathrm{~h}$ in the dark in triplicate. Concentrations of chlorophyll and carotenoids were measured using absorbance recorded at 662, 644, and $440 \mathrm{~nm}$ for maximum absorption of Chl-a, Chl-b, and carotenoids, respectively. The extinction coefficients were determined by an Ultraviolet spectrophotometer (SECOMAM, Anthelie Advanced 5). Pigment contents were calculated in milligram per gram of fresh leaf weight (FW) by applying the absorption coefficient equations described by Lichtenthaler (1986) and Aliu et al. (2013; 2014):

Chl-a $\left(\mathrm{mg} \mathrm{g}^{-1} \mathrm{FW}\right)=[9.784(\mathrm{OD} 662)-0.99(\mathrm{OD} 644)]$ $\times \mathrm{V} / \mathrm{FW}$,

Chl-b $\left(\mathrm{mg} \mathrm{g}^{-1} \mathrm{FW}\right)=[21.426(\mathrm{OD} 644)-4.65(\mathrm{OD} 662)]$ $\times \mathrm{V} / \mathrm{FW}$,

Carotenoids $\left(\mathrm{mg} \mathrm{g}^{-1} \mathrm{FW}\right)=[4.695(\mathrm{OD} 440)-0.268$ $(C h-a+C h l-b)] \times \mathrm{V} / \mathrm{FW}$,

where FW is the fresh leaf weight, OD is the optical density, and $\mathrm{V}$ is the volume of the sample.

\subsection{Statistical analyses}

SPSS version 19 was used for the analysis of variance for all parameters and to compare treatment means by Duncan's multiple range test. Linear relationships among the traits were assessed by Pearson correlation analysis. Pearson coefficient was used to calculate the correlations between the assessed parameters.

\section{Results and discussion}

The influence of Se on plants largely depends on its chemical form and its concentration in nutrient solution (Combs, 2001). A stimulating effect with a Se dose of $1.30 \mathrm{mg} \mathrm{kg}^{-1}$ on plant growth has been observed, whereas with a Se concentration of $6.57 \mathrm{mg} \mathrm{kg}^{-1}$, the maize growth (both shoots and roots) was impaired compared to the control and further decreased with higher Se concentrations (Table 1). The biomass decreases with Se doses of $\geq 6.57 \mathrm{mg} \mathrm{kg}^{-1}$ was stronger for shoots than for roots. With the highest Se dose, the biomass of shoots was lower by $80.3 \%$ (hybrid) or $84.4 \%$ (LP) and of roots by $60.0 \%$ (hybrid) or $50.7 \%$ (LP), respectively, compared to the control. Also Hartikainen et al. (2000) have shown that Se effects on plants depend on the concentrations; with lower doses, Se stimulated the growth of ryegrass seedlings, whereas with higher doses, it acted as pro-oxidant, reducing yields and inducing metabolic disturbances. The shoot-to-root 
Table 1. Influence of selenium on shoot and root biomass of single maize plants and the shoot-to-root ratio

Tabelle 1. Einfluss von Selen auf die Spross- und Wurzeltrockenmasse von Mais (pro Pflanze) sowie das Sproß/Wurzel-Verhältnis

\begin{tabular}{|c|c|c|c|c|c|c|}
\hline \multirow[t]{2}{*}{$\mathrm{Se}\left(\mathrm{mg} \mathrm{kg}^{-1}\right)$} & \multicolumn{2}{|c|}{ Shoot $\left(\right.$ g plant $\left.^{-1}\right)$} & \multicolumn{2}{|c|}{ Root $\left(\mathrm{g} \mathrm{plant}^{-1}\right)$} & \multicolumn{2}{|c|}{ Shoot-to-root ratio } \\
\hline & $\mathrm{H}$ & LP & $\mathrm{H}$ & LP & $\mathrm{H}$ & LP \\
\hline Control & $2.987^{\mathrm{b}}$ & $3.012^{\mathrm{b}}$ & $0.895^{\mathrm{b}}$ & $0.789^{\mathrm{b}}$ & $3.34^{\mathrm{a}}$ & $3.85^{\mathrm{a}}$ \\
\hline 1.30 & $4.587^{\mathrm{a}}$ & $4.789^{\mathrm{a}}$ & $1.586^{\mathrm{a}}$ & $1.689^{\mathrm{a}}$ & $2.90^{\mathrm{b}}$ & $2.84^{\circ}$ \\
\hline 6.57 & $2.258^{\mathrm{c}}$ & $2.158^{c}$ & $0.789^{c}$ & $0.678^{c}$ & $2.88^{c}$ & $3.20^{\mathrm{b}}$ \\
\hline 13 & $1.178^{\mathrm{d}}$ & $1.124^{\mathrm{d}}$ & $0.487^{\mathrm{d}}$ & $0.451^{\mathrm{d}}$ & $2.43^{\mathrm{d}}$ & $2.48^{\circ}$ \\
\hline 26 & $0.587^{\mathrm{e}}$ & $0.469^{\mathrm{e}}$ & $0.358^{e}$ & $0.389^{e}$ & $1.65^{\mathrm{e}}$ & $1.21^{\circ}$ \\
\hline
\end{tabular}

$\mathrm{H}$, hybrid; LP, local population.

Means in each column followed by the same letter are not significantly different.

ratio was highest in the control for both genotypes and decreased with higher Se doses reaching the lowest values with the highest Se dose. Even with a dose of $1.30 \mathrm{mg} \mathrm{kg}^{-1}$, which enhanced both shoot and root biomass, the shootto-root ratio was lower than that of the control. Contrary to that, aqueous above-ground biomass extracts of catch crops stronger impaired root than shoot growth of maize seedling and thus increased the shoot-to-root ratio (Chovancová et al., 2015).

The chlorophyll (Chl-a and Chl-b) contents were affected by Se application in both maize genotypes (Table 2). There was a clear trend of Chl-a reduction with increasing Se concentration. Se application of $26 \mathrm{mg} \mathrm{kg}^{-1}$ reduced Chl-a by $67.8 \%$ (hybrid) or $54.6 \%$ (LP), respectively, compared to the control. Contrary to that, Chl- $b$ increased with applications of Se up to $6.57 \mathrm{mg} \mathrm{kg}^{-1}$ before the values decreased again with higher Se application rates. With $6.57 \mathrm{mg} \mathrm{Se} \mathrm{kg}{ }^{-1}$, Chl-b was 15.1-fold (hybrid) or 1.6-fold (LP), respectively, higher compared to the control. Lowest Chl- $b$ was observed in the control (hybrid) or with $26 \mathrm{mg} \mathrm{Se} \mathrm{kg}^{-1}$ (LP). The Chl-b contents in the hybrid were strongly affected by Se application compared to those in the LP. This might be because the LP has large genetic variation to adapt to environmental stress tolerance, as a result of natural selection. Total chlorophyll ( $a$ and $b$ ) was high-

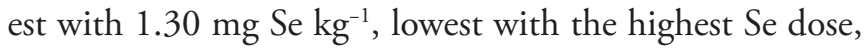
and second lowest with the control.

Excessive Se concentrations not only reduced the physiological activities (Nowak et al., 2004) but also reduced the chlorophyll content (Nawaz et al., 2013). Rani et al. (2005) reported that the critical Se concentration in plant tissues, above which the yield in maize decreased, was $77 \mu \mathrm{g} \mathrm{g}^{-1} \mathrm{DW}$. Also Nashmin et al. (2015) showed an effect of Se on Chl-a and Chl-b contents with the highest Se addition causing an increase in the Chl- $a$ and Chl- $b$ contents at all growth stages compared to the control. Nawaz et al. (2016) observed that the exposure to drought stress in plant applied with Se significantly reduced leaf photosynthetic pigments such as $C h l-a, C h l-b$, and carotenoids contents by $75 \%, 60 \%$, and $71 \%$ respectively, compared to the control. Garousi (2016) showed that Chl-a and Chl$b$ were not impaired after 3 weeks of Se exposure up to

Table 2. Influence of selenium on chlorophyll and carotenoid concentrations of maize $(n=3)$

Tabelle 2. Einfluss von Selen auf den Chlorophyll- und Carotinoidgehalt von Mais $(\mathrm{n}=3)$

\begin{tabular}{|c|c|c|c|c|c|c|c|c|}
\hline \multirow[t]{3}{*}{ Se $\left(\mathrm{mg} \mathrm{kg}^{-1}\right)$} & \multicolumn{2}{|c|}{ Chlorophyll $a$} & \multicolumn{2}{|c|}{ Chlorophyll $b$} & \multicolumn{2}{|c|}{ Total chlorophyll ( $a$ and $b$ ) } & \multicolumn{2}{|c|}{ Carotenoids } \\
\hline & $\mathrm{H}$ & LP & $\mathrm{H}$ & LP & $\mathrm{H}$ & LP & $\mathrm{H}$ & LP \\
\hline & \multicolumn{8}{|c|}{$\left(\mathrm{mg} \mathrm{g}^{-1} \mathrm{FW}\right)$} \\
\hline Control & $12.73^{\mathrm{a}}$ & $7.21^{\mathrm{a}}$ & $1.20^{\mathrm{d}}$ & $5.27^{\mathrm{d}}$ & $13.93^{\mathrm{d}}$ & $12.48^{\mathrm{d}}$ & $8.41^{\mathrm{b}}$ & $2.68^{\mathrm{a}}$ \\
\hline 1.30 & $8.65^{\mathrm{b}}$ & $5.17^{\mathrm{b}}$ & $12.31^{\mathrm{b}}$ & $13.20^{\mathrm{ab}}$ & $20.96^{a}$ & $18.37^{\mathrm{a}}$ & $9.12^{\mathrm{a}}$ & $2.20^{\mathrm{ab}}$ \\
\hline 6.57 & $6.31^{\mathrm{c}}$ & $4.34^{\mathrm{c}}$ & $18.11^{\mathrm{a}}$ & $13.48^{\mathrm{a}}$ & $24.42^{\mathrm{b}}$ & $17.82^{\mathrm{ab}}$ & $4.51^{\mathrm{c}}$ & $0.30^{\mathrm{b}}$ \\
\hline 13 & $5.23^{\mathrm{c}}$ & $4.44^{\mathrm{c}}$ & $8.89^{c}$ & $12.47^{\mathrm{b}}$ & $14.12^{\mathrm{c}}$ & $16.91^{\mathrm{c}}$ & $4.31^{\mathrm{c}}$ & $0.30^{\mathrm{b}}$ \\
\hline 26 & $4.10^{\text {cd }}$ & $3.27^{\mathrm{d}}$ & $0.61^{\mathrm{e}}$ & $6.23^{\mathrm{c}}$ & $4.71^{\mathrm{e}}$ & $9.51^{\mathrm{e}}$ & $0.85^{\mathrm{d}}$ & $0.04^{c}$ \\
\hline
\end{tabular}

$\mathrm{H}$, hybrid; LP, local population; FW, fresh leaf weight.

Means in each column followed by the same letter are not significantly different. 
$3 \mathrm{mg} \mathrm{l}^{-1}$ from $\mathrm{Se}^{\mathrm{IV}}$ or $\mathrm{Se} \mathrm{V}^{\mathrm{VI}}$, although reductions in the efficiency of the PSII photochemistry (This parameter measures the proportion of light absorbed from photo system II( PSII ) that is used in photochemistry ) occurred in the $\mathrm{Se}^{\mathrm{VI}}$ treatment (but not in the $\mathrm{Se}^{\mathrm{IV}}$ treatment).

The carotenoid content showed a relatively wide range across the Se treatments (Table 2). For the hybrid, the highest content of carotenoids was observed in the control and the lowest with the highest Se application (where it was lower by about $90 \%$ compared with the control). The overall contents were lower in the LP than in the hybrid. In the LP, carotenoids increased with the first Se dose compared to the control and then strongly decreased with higher doses. With the highest Se dose, the carotenoids were lower by $99 \%$ compared to the control. Similarly, Manion et al. (2014) also reported from solution culture with watercress that with increasing Se doses, the carotenoid contents decreased linearly.

For both genotypes, Chl-a concentration was positively correlated with carotenoids, shoot biomass, and shoot-toroot ratio, but for the hybrid, it also correlated with root biomass. There was no correlation of Chl- $a$ with total chlorophyll ( $a$ and $b$ ). Chl- $b$ was among all parameters only positively correlated with total chlorophyll $(a$ and $b$ ) (in both genotypes). Carotenoids were (next to Chl-a) positively correlated with root and shoot biomass and shootto-root ratio; for the hybrid, it also positively correlated with total chlorophyll ( $a$ and $b$ ), but for both genotypes, it does not correlated with Chl-b. Total chlorophyll ( $a$ and $b$ ) was (next to $C h l-b$ ) positively correlated with root and shoot biomass; for the LP, it was also positively correlated with the shoot-to-root ratio. The root biomass was (next to already mentioned parameters) positively correlated with the shoot biomass and also with the shoot-to-root ratio for the LP. Shoot biomass was positively correlated to shootto-root ratios for the hybrid and the LP (Table 3).

\section{Conclusion}

Our study provided some evidence that higher concentrations of Se in the plant growth medium may reduce the chlorophyll content including Chl-a and Chl-b. These green pigments play a key role in photosynthesis and their content in crop leaves is of great importance for nutritional state diagnosis and yield formation. A Se concentration of $1.30 \mathrm{mg} \mathrm{kg}^{-1}$ even stimulated plant growth, whereas concentrations of 13 and $26 \mathrm{mg} \mathrm{kg}^{-1}$ dramatically reduced plant biomass, also affecting the root system. Positive correlations were observed between Chl- $a$ and carotenoids with shoot (for both genotypes) and root (for one genotypes) biomass; whereas no correlation was observed between Chl- $b$ and biomass. We can conclude that low amounts of Se application are favorable for both plant growth and chlorophyll and carotenoids contents, whereas high amounts of Se application negatively affect both.

Table 3. Pearson correlation coefficients for maize traits across different selenium treatments. The white areas show the correlation for the local population, the gray area for the hybrid.

Tabelle 3. Pearsons Korrelationskoeffizienten für die Merkmale von Mais. Die weiße Fläche zeigt die Korrelation für die lokale Population, die graue für den Hybrid.

\begin{tabular}{|c|c|c|c|c|c|c|c|}
\hline Correlated traits & Chl-a & $C h l-b$ & Carotenoids & $\begin{array}{l}\text { Total chlorophyll } \\
\qquad(a \text { and } b)\end{array}$ & Root BM & Shoot BM & $\begin{array}{c}\text { Shoot-to-root } \\
\text { ratio }\end{array}$ \\
\hline$C h l-a$ & & -0.294 & $0.828^{* *}$ & 0.071 & 0.362 & $0.598^{*}$ & $0.860^{* *}$ \\
\hline$C h l-b$ & -0.191 & & 0.166 & $0.933^{* *}$ & 0.378 & 0.298 & 0.308 \\
\hline Carotenoids & $0.845^{* *}$ & 0.191 & & 0.485 & $0.797^{* *}$ & $0.925^{* *}$ & $0.878^{* *}$ \\
\hline $\begin{array}{l}\text { Total chlorophyll } \\
(a \text { and } b)\end{array}$ & 0.264 & $0.896^{* *}$ & $0.570^{*}$ & & $0.529^{*}$ & $0.535^{*}$ & $0.692^{* *}$ \\
\hline Root BM & $0.553^{*}$ & 0.386 & $0.860^{* *}$ & $0.629^{*}$ & & $0.955^{* *}$ & $0.739^{* *}$ \\
\hline Shoot BM & $0.675^{* *}$ & 0.355 & $0.922^{* *}$ & $0.653^{* *}$ & $0.986^{* *}$ & & $0.614^{* *}$ \\
\hline $\begin{array}{l}\text { Shoot-to-root } \\
\text { ratio }\end{array}$ & $0.859^{* *}$ & 0.115 & $0.797^{* *}$ & 0.445 & 0.361 & $0.616^{*}$ & \\
\hline
\end{tabular}

BM, biomass.

Correlation is significant at $\mathrm{p}<0.05\left(^{*}\right)$ or $\left.\mathrm{p}<0.01{ }^{(* *}\right)$. 


\section{References}

Aichberger, K. and G.F. Hofer (1989): Arsen-, Quecksilber- und Selengehalte landwirtschaftlich genutzter Böden Oberösterreichs. Die Bodenkultur 40, 1-11.

Aliu, S., Fetahu, Sh. and L. Rozman (2010): Variation of physiological traits and yield components of some maize hybrid (Zea mays L.) in agro-ecological conditions of Kosovo. Acta Agriculturae Slovenica 95, 35-41.

Aliu, S., Gashi, B., Rusinovci, I., Fetahu, S. and R. Vataj (2013): Effects of some heavy metals in some morphological and physiological parameters in maize seedlings. American Journal of Biochemistry and Biotechnology 9, 27-33.

Aliu, S., Rusinovci, I., Gashi, B., Kaul, H.-P., Rozman, L. and Sh. Fetahu (2014): Genetic diversity for mineral content and photosynthetic pigments in local bean (Phaseolus vulgaris L.) populations. Journal of Food, Agriculture \& Environment 12, 635-639.

Chovancová, S., Neugschwandtner, R.W., Ebrahimi, E. and H.-P. Kaul (2015): Effects of aqueous aboveground biomass extracts of cover crops on germination and seedlings of maize. Die Bodenkultur 66, 17-23.

Combs, G.F. (2001): Selenium in global food systems. British Journal of Nutrition 85, 517-547.

Czyczyło-Mysza, I., Tyrka, M., Marcińska, I., Skrzypek, E., Karbarz, M., Dziurka, M., Hura, T., Dziurka, K. and S.A. Quarrie (2013): Quantitative trait loci for leaf chlorophyll fluorescence parameters, chlorophyll and carotenoid contents in relation to biomass and yield in bread wheat and their chromosome deletion bin assignments. Molecular Breeding 321, 189-210.

Edelbauer, A. und G. Eder (2001): Auswirkungen unterschiedlicher Düngungsmaßnahmen im Dauergrünland auf den Selengehalt im Boden und im Aufwuchs. Die Bodenkultur 52, 209-214.

Filek, M., Keskinen, R., Hartikainen, H., Szarejko, I., Janiak, A., Miszalski, Z. and A. Golda (2008): The protective role of selenium in rape seedlings subjected to cadmium stress. Journal of Plant Physiology 165, 833-844.

Garousi, F., Veres, S., Bódi, É., Várallyay, S. and B. Kovács (2015a): Role of selenite and selenate uptake by maize plants in chlorophyll a and b content. World Academy of Science, Engineering and Technology International Journal of Agricultural and Biosystems Engineering 9, 625-628.
Garousi, F., Veres, S. and B. Kovács (2015b): Non-destructive and destructive measurements' chlorophyll content in sunflower and maize plants uptaken different chemical forms of selenium. Columella - Journal of Agricultural and Environmental Sciences 2, 9-15.

Garousi, F. (2016): Accumulation of Selenium in the main parts of crop grown in soils and hydroponics. PhD Thesis. University of Debrecen, Hungary.

Gitelson, A., Gritz, Y. and M.N. Merzlyak (2003): Relationships between leaf chlorophyll content and spectral reflectance and algorithms for non-destructive chlorophyll assessment in higher plant leaves. Journal of Plant Physiology 160, 271-282.

Gul, H., Kinza, S., Shinwart, Z.K. and M. Hamayun (2017): Effect of selenium on the biochemistry of zea mays under salt stress. Pakistan Journal of Botany 49, $25-32$.

Hartikainen, H., Xue, T. and V. Piironen (2000): Seleni$\mathrm{um}$ as an anti-oxidant and pro-oxidant in ryegrass. Plant and Soil 225, 193-200.

Kabata, A. (2001): Trace Elements in Soils and Plants. $3^{\text {rd }}$ ed., CRC Press, Boca Raton, FL, USA, pp. 241-252.

Manion, L.K., Kopsell, D.E., Kopsell, D.A., Sams, C.E. and R.L. Rhykerd (2014): Selenium fertilization influences biomass, elemental accumulations, and phytochemical concentrations in watercress. Journal of Plant Nutrition 37, 327-342.

Lichtenthaler, H.K., Buschmann, C., Rinderle, U. and G. Schmuck (1986): Application of chlorophyll fluorescence in ecophysiology. Radiation and Environmental Biophysics 25, 297-308.

Longchamp, M, Angeli N. and M. Castrec-Rouelle (2011): Uptake of selenate and/or selenite in hydroponically grown maize plants and interaction with some essential elements (calcium, magnesium, zinc, iron, manganese, and copper). The Second International Conference on Selenium in the Environment and Human Health, China.

Nashmin, E., Hartikainen, H., Simojoki, A., Hajiboland, R. and M. Seppanen (2015): Dynamics of dry matter and selenium accumulation in oilseed rape (Brassica napus L.) in response to organic and inorganic selenium treatments. Agricultural and Food Science 24, 104-117. Nawaz F., Muhammad, N., Muhammad, Y., Ashraf, M., Zulfiqar, M., Muhammad, S., Rana, N. and A. Muhammad (2016): Selenium supplementation affects physiological and biochemical processes to improve fod- 
der yield and quality of maize (Zea mays L.) under water deficit Conditions. Frontiers in Plant Science 7, 1438.

Nawaz, F., Ashraf, M.Y., Ahmad, R. and E.A. Waraich (2013): Selenium (Se) seed priming induced growth and biochemical changes in wheat under water deficit conditions. Biological Trace Element Research 151, 284-293.

Nowak, J., Kaklewski, K. and M. Ligocki (2004): Influence of selenium on oxidoreductive enzymes activity in soil and plants. Soil Biology \& Biochemistry 36, 15531558.

Placzek, A. and B. Patorczyk-Pytlik (2014): Effect of form and dose of selenium on yielding and contents of macronutrients in maize. Ecological Chemistry and Engineering A 21, 241-252.

Rani, N., Dhillori, K.S. and S.K. Dhillon (2005): Critical levels of selenium in different crops grown in an alkaline salty loam soil treated with selenite-Se. Plant and Soil 277, 367-374.

Spallholz, J. and D. Hoffman (2002): Selenium toxicity: Cause and effects in aquatic birds. Aquatica Toxicology 57, 27-37.

Sager, M. (2002): Vertical mobility of selenium, arsenic and sulfur in model soil columns. Die Bodenkultur 53, 83-103.

Száková J., Praus L., Tremlová J., Kulhánek, M. and P. Tlustoš (2017): Efficiency of foliar selenium applica- tion on oilseed rape (Brassica napus L.) as influenced by rainfall and soil characteristics. Archives of Agronomy and Soil Science 63, 1240-1254.

Taiz, L. and E. Zeiger (2009): Plant Physiology. $4^{\text {th }}$ ed., Sinauer Associates, Massachusetts, MA, USA.

Terry, N., Zayed, A.M., Souza, M.P. and A.S. Tarun (2000): Selenium in higher plants. Annual Review of Plant Physiology and Plant Molecular Biology 51, 401432.

Hoewyk, D. (2013): A tale of two toxicities: malformed selenoproteins and oxidative stress both contribute to selenium stress in plants. Annals of Botany 112, 965972.

Vikhreva, V.A., Balakhnina, T.I. and V.K. Gins (2002): Effect of selenium on intensity of peroxide processes and enzyme activity in Caucasian goat's rue leaves under extreme growing condition. Russian Agricultural Sciences $2,1-4$.

Wang, F., Wang, G., Li, X., Huang, J. and J. Zheng (2008): Heredity, physiology and mapping of a chlorophyll content gene of rice (Oryza sativa L.). Journal of Plant Physiology 165, 324-330.

Withnall, R., Chowdhry, B.Z., Silver, J., Edwards, H.G.M. and L.F.C. de Oliveira (2003): Raman spectra of carotenoids in natural products. Spectrochimica Acta, Part A: Molecular and Biomolecular Spectroscopy 59, 2207-2212. 